\title{
Role of estrogen in hepatocellular carcinoma: is inflammation the key?
}

\author{
Liang Shi, Yili Feng, Hui Lin, Rui Ma and Xiujun Cai
}

\begin{abstract}
Hepatocellular carcinoma (HCC) is one of the most common malignancies worldwide and accounts for the third-leading cause of cancer-related deaths. Over the past decades, advances have been made in the field of surgery, but effective treatment of HCC is lacking. Due to a marked male predominance in morbidity and mortality in HCC patients, it has long been considered that sex hormones play a role in HCC development. Recently estrogen has been proven to exert protective effects against HCC through IL-6 restrictions, STAT3 inactivation and tumour-associated macrophage inhibition. While IL-6-dependent STAT3 activation is considered a key event in inflammation-induced liver cancer, the anti-inflammation effect of estrogen is well documented. The roles of the estrogen receptor and aromatase and interactions between microRNAs and estrogen in HCC have been investigated. In this review, we present a novel model to elucidate the mechanism of estrogen-mediated inhibition of HCC development through an anti-inflammation effect and provide new insights into the roles of estrogen in liver disease.
\end{abstract}

Keywords: Estrogen, Estrogen receptor, Hepatocellular carcinoma, Inflammation

\section{Introduction}

The treatment of liver cancer is a difficult task, especially among end-stage patients, whose lesions are usually thought to be unresectable. The development of $\mathrm{HCC}$ is considered the end result of most liver diseases, including viral hepatitis, cirrhosis and alcoholic liver disease. As a result of high-grade malignancy and lack of effectiveness of medical treatment, HCC is the thirdleading cause of cancer deaths worldwide [1]. Furthermore, the incidence of HCC shows a regional divergence due to aetiology. In high-risk areas such as Southeast Asia and China, hepatitis B virus (HBV) infection, together with aflatoxin exposure, is the predominant risk factor. However, hepatitis $\mathrm{C}$ virus (HCV) infection has emerged as a more significant risk factor in Japan, North America and Europe. In these developed countries, the incidence of $\mathrm{HCC}$ is increasing [2,3].

Until now, only sorafenib is used as first-line therapy for patients with advanced HCC $[4,5]$. Sorafenib therapy for HCC has been proven to be safe and effective. Despite a statistically significant and clinically relevant improvement

\footnotetext{
* Correspondence: cxjzu@zju.edu.cn

Chawnshang Chang Live Cancer Center, Department of General Surgery, Sir Run-Run Shaw Hospital, Zhejiang University, Hangzhou 310016, China
}

in median overall survival (OS) with sorafenib, some important questions of its application in advanced HCC remain unanswered [6]. For the better use of sorafenib in the clinical setting, the dosage, outcome prediction based on side effects and application of modified Response Evaluation Criteria in Solid Tumours (mRECIST) require more evaluation. Interested in obvious gender disparity in HCC occurrence $[7,8]$, researchers have attempted to investigate the molecular mechanism underlying such disparity and developed effective therapy using sex hormones. Recently, work by Ma et al. showed an exciting potential of the combination of sorafenib and hormonerelated therapy in $\mathrm{HCC}$, which will be a better way to control advanced HCC [9].

Unlike breast and prostate cancer, which are modulated by estrogen and androgen, respectively, HCC may be modulated by both sex hormones during its initiation, progression and metastasis $[8,10,11]$. Elevated levels of androgen are considered to promote tumourigenesis, while studies in the past decades showed that the roles of estrogen in HCC are diverse, even opposite [8,12-14]. Fortunately, recent progress has shed some light on the precise mechanism of estrogen action in HCC. Although many aspects are still unknown, the anti-HCC activity of 
estrogen has been wildly accepted, and its protective effect might be related to its anti-inflammation effect. We thus assume that this anti-inflammation effect may provide a key to understanding the role of estrogen in HCC. More importantly, the anti-inflammation nature of estrogen may yield a new, promising approach to treat HCC. In this review, we focus on recent studies regarding the potential roles of estrogen in HCC.

\section{Early clinical trials of anti-estrogen therapy for HCC}

At the very beginning of anti-estrogen therapy in medical practice, clinicians were inspired by the success of tamoxifen, which is a competitive antagonist of the estrogen receptor (ER), as a treatment for ER-positive breast cancer. In addition, estrogen was found to promote HCC in rats [15-19]. Some reports also showed that oral contraceptives (OCPs) led to a higher incidence of liver diseases such as focal nodular hyperplasia, liver haemangioma and hepatocellular adenoma, which are considered premalignant stages of HCC $[20,21]$. However, a systematic review concluded that no benefits could be gained by anti-estrogen in regards to overall survival and life quality [22]. And it is also suggested that OCPs might not to be a risk factor for HCC [23]. As a result, several hypotheses were proposed to explain the failures of using anti-estrogen in treating HCC, including the dysfunction induced by variant ER- $\alpha$ (vER- $\alpha$ ) $[24,25]$, regulation by the postreceptor signalling pathway and treatment with an insufficient therapy dose $[26,27]$. With further investigations, estrogen was found to suppress HCC [28], and this was supported by epidemiology data, which suggested an elevated incidence of HCC in postmenopausal female and suppression of such phenomenon by estrogen treatment $[29,30]$. Moreover, the prognosis of female HCC patients is much better than male patients [31]. These findings all imply that estrogen may act as a protective factor against HCC. Unfortunately, estrogen-related treatment is still impractical so far due to our limited knowledge [22].

\section{ER-a may be crucial to the estrogen-induced effect on HCC}

The initiation of the canonical estrogen pathway depends on the binding of estrogen and its receptor. The ligand-bound ER then recognizes the estrogen response element (ERE) and regulates the transcription of target genes. Two subtypes of ERs have been found to date, ER- $\alpha$ and ER- $\beta$. Both ER subtypes are expressed in HCC and interact with each other [32]. Studies have shown that ER subtypes exert multiple functions in various stages of liver disease and participate in an extremely complicated signal transduction process. The different roles of the ER subtypes in liver disease, especially ER- $\beta$, have yet to be fully elucidated. Nevertheless, ER- $\alpha$ has been identified for a long time and has been extensively investigated [8].

Wild type ER- $\alpha$ (wtER- $\alpha$ ) contains 595 amino acid residues with a molecular mass of $66 \mathrm{kDa}$. It consists of a ligand-independent activation function domain (AF-1), a central DNA-binding domain (DBD) and a hormonebinding domain (HBD, also named ligand-dependent activation function domain, AF-2). The DBD and the HBD are linked by a hinge region [33]. Different ER- $\alpha$ splice variants, including ER- $\alpha \Delta 5$ (incomplete $\mathrm{HBD}$ ), ER $\alpha-46$ (AF-1 deleted) and ER $\alpha$-36 (AF-1 deleted and incomplete HBD), have been identified in the liver (Figure 1) $[34,35]$. The ER- $\alpha$ variants have been proven to be strong negative predictors for HCC [25,36,37]. ER- $\alpha \Delta 5$ and hepatitis B virus $\mathrm{X}$ protein $(\mathrm{HBx})$ can repress the transcriptional activity of wtER- $\alpha$ through an $17 \beta$-estradiol (E2)-independent method, and histone deacetylase-1 (HDAC-1) seems to be involved in the process [38].

A different expression pattern of $\mathrm{vER}-\alpha$ can be observed in normal liver, cirrhosis and HCC tumour tissues (Table 1) [34], and a similar result can be obtained in liver cell lines. Furthermore, ER- $\alpha$ seems to lose function during liver disease progression, and dysfunctional ER- $\alpha$ could contribute to $\mathrm{HCC}$ development. In addition, ER $\alpha-36$ negatively regulates the transcriptional activity of ER-66 and ER- $\beta$ [39]. This crosstalk between ER subtypes forms a part of the complex ER signalling and has yet to be confirmed in HCC.

However, vER- $\alpha$ is considered a predictor of poor prognosis both in HCC and breast cancer [33]. In multiple-factor analysis, the ER- $\alpha$ type and bilirubin level were two independent risk factors for HCC [36]. The worst prognosis appears in patients with vER- $\alpha$ and hepatitis B surface antigen (HBS-Ag), and this may be explained by the suppression of transcriptional activity of the ER- $\alpha$ by HBx and ER- $\alpha \Delta 5$. In addition, HBV infection could lead to genomic instability, which may contribute to the expression of vER- $\alpha$ [40]. Although tumour size was not obviously different in groups with different ER $\alpha$ types, vER- $\alpha$-positive HCC presents a rapid growth rate and an increased ability of metastasis [36]. Therefore, vER- $\alpha$-positive patients usually die of massive tumour invasion. In contrast, slow progressive liver failure due to cirrhosis kills wtER- $\alpha$-positive HCC patients. Based on this finding, Villa et al. proposed that the treatment for wtER- $\alpha$ HCC patients should focus on chronic liver failure [36,41]. Furthermore, vER- $\alpha$ in chronic hepatitis and cirrhosis is also associated with high levels of oxidative stress-induced DNA damage and c-myc expression [42].

Recently, hypomethylation of the long interspersed nuclear element-1 (LINE-1) promoter was reported to correlate with poor outcomes of HCC [43]. Before this finding, LINE-1 hypomethylation was more frequently 


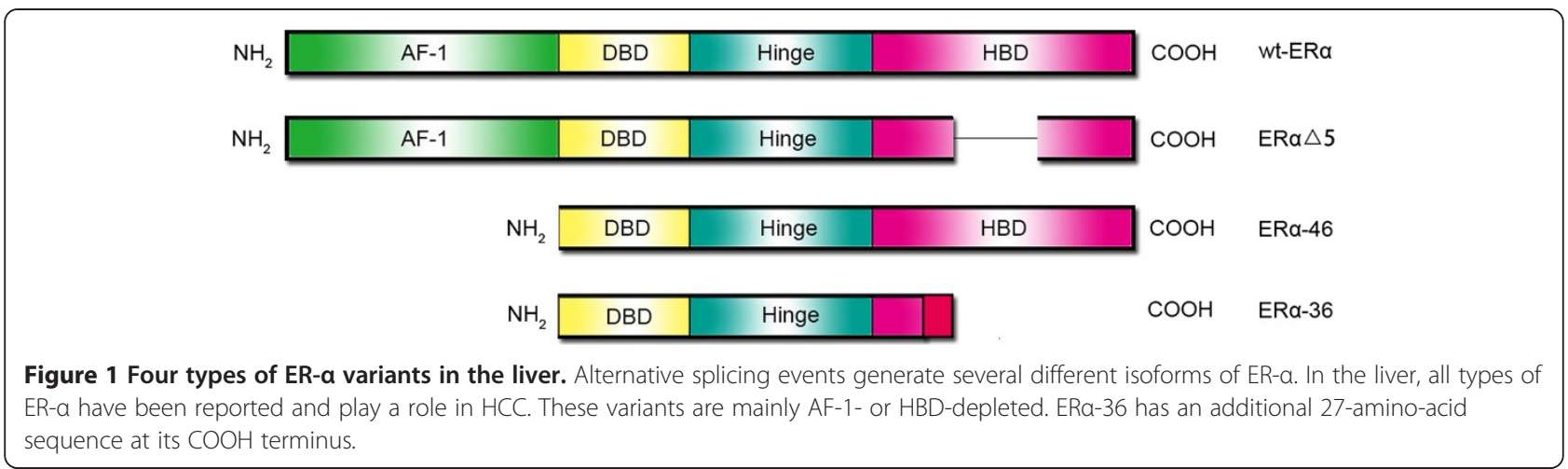

observed in hepatitis-related HCC to be accompanied by methylation of the ER promoter $[44,45]$. This hypermethylation of $\mathrm{CpG}$ islands in wtER genes may partially contribute to the significant downregulation of wtER and upregulation of vER- $\alpha$ in HCC [46]. The mechanism by which the expression pattern of the ER- $\alpha$ subtype is changed during liver tumourigenesis remains largely unknown. With more conclusive evidence, the expression pattern of the ER- $\alpha$ subtypes could serve as a potential prognostic indicator for $\mathrm{HCC}$ and provide a novel target for HCC treatment.

\section{Anti-inflammation effects of estrogen}

The multitasking role of estrogen in inflammation is dependent on its concentration, cell type and context, and the anti-inflammation effect of estrogen has been further confirmed in many disease models, including liver disease. If $\mathrm{B}$ cell-dependent immunity or an overshooting fibrotic tissue repair process does not play a central role, estrogen would have a protective effect in chronic inflammatory diseases [47]. Some cytokines contribute to the occurrence of liver disease, and possible effects of estrogen on the release of proinflammatory cytokines in vitro have been discussed in a previous review (Table 2) [47].

Moreover, estrogen could inhibit the NF- $\mathrm{B}$ pathway and block the expression of adhesion molecules. Inflammation factors, such as nitric oxide (NO) and reactive oxygen species (ROS) production are also downregulated in inflammation milieus. Given the emerging concept of cancer-related inflammation, it is of scientific and clinical interest to explore the possibility of using the antiinflammation effect of estrogen in HCC prevention.

Table 1 The expression pattern of ER-a subtypes in different liver tissues

\begin{tabular}{llll}
\hline & Normal liver & Cirrhosis & HCC \\
\hline ERa-66 & High & Moderate & None \\
ERa-46 & Moderate & Moderate & Moderate \\
ERa-36 & None & Moderate & High \\
\hline
\end{tabular}

\section{IL-6 inhibition by estrogen}

Hepatoma has been considered an inflammation-related cancer caused by chronic hepatitis [59-61]. During chronic inflammation, proinflammatory cytokines and immune cells create a tumour microenvironment that influences hepatocarcinogenesis. Among these, IL-6 is believed to be a key component in inflammation-associated tumourigenesis [62-64]. More importantly, estrogen has a significant impact on the production of IL-6. Preliminary studies showed that elevated IL-6 expression was associated with a high rate of metastasis and poor prognosis in HCC [63-65]. Concordant evidence from Naugler's group showed that MyD88-dependent production of IL-6 contributed to gender disparity of HCC because IL- 6 ablation protected male mice from $\mathrm{HCC}$ and that estrogen inhibited IL-6 production [51].

In the liver, the release of IL-6 from Kupffer cells (KCs) is modulated by MyD88-dependent NF- $\mathrm{KB}$ signaling, whose activation is triggered by IL- $1 \alpha$ from dying hepatocytes [66-68]. According to the report by Naugler et al., E2 treatment could reduce diethylnitrosamine (DEN)-induced liver injury by inhibiting IL-6 production from KCs [51]. Moreover, E2 also provides protection in IL-6-treated mice, which suggests that E2 may inhibit downstream IL-6 signalling. The inhibition of the IL-6 promoter activity through inactivation of NF- $\mathrm{kB}$ and $\mathrm{C} /$ EBP $\beta$ causes downregulation of IL-6 [69]. These studies provide promising evidence for the higher incidence of HCC in males than females based on the role of IL- 6 in anti-inflammatory effects [70]. However, a recent study on Forkhead box A (Foxa)-deficient mice showed that the IL-6 level did not correlate with tumour load when Foxa1/2 were only ablated in hepatocytes [71]. However, inflammatory monocytes that were recruited from circulation after $\mathrm{HCC}$ initiation exerted multiple effects on the tumour microenvironment. During HCC progression, tumour-associated macrophages (TAMs) replace $\mathrm{KCs}$ as the dominant modulator [61]. Taken together, these findings suggest that IL-6 is one of the regulators involved in the sexual dimorphism of HCC. 


\begin{tabular}{|c|c|c|}
\hline Cytokines & Effects of estrogen on cytokine production & References \\
\hline IL-1 & Heterogeneous, depends on E2 concentration & {$[48,49]$} \\
\hline IL-6 & $\begin{array}{l}\text { Mostly inhibition, promotion in synoviocytes } \\
\text { (related to RA) }\end{array}$ & {$[48,50,51]$} \\
\hline $\mathrm{IL}-8$ & Inhibition & {$[52,53]$} \\
\hline TNF & Mostly inhibition & {$[48,54]$} \\
\hline $\mathrm{IFN}-\gamma$ & Heterogeneous, depends on cell type & {$[54,55]$} \\
\hline $\mathrm{IL}-4$ & Promotion & {$[55]$} \\
\hline IL-10 & Mostly promotion & {$[54,56]$} \\
\hline TGF- $\beta$ & Promotion & {$[57,58]$} \\
\hline
\end{tabular}

RA: rheumatoid arthritis.

\section{Effects of estrogen on STAT3 activity}

Signal transducer and activator of transcription-3 (STAT3) has been identified as a key regulator of macrophage functions and is involved in several programmes related to tumour progression [72-75]. Moreover, STAT3 signalling is a central signalling hub in cancer-related inflammation. The inflammatory microenvironment is orchestrated by numerous cytokines, chemokines and other mediators, and STAT3 is critical in regulating these inflammatory factors, such as IL-6, macrophage colony-stimulating factor, prostaglandin and cyclooxygenase-2 [76]. In STAT3deficient mice, the liver tumour load caused by DEN treatment was significantly reduced [77]. In addition, the JAK/ STAT3 pathway was enhanced in suppressor of cytokine signalling-3 (SOCS3) knockout mice, which were sensitive to hepatitis-induced hepatocarcinogenesis [78]. STAT3 signalling is negatively regulated through feedback loops. However, the polarization of macrophages to the M2 phenotype disturbs this homeostasis and keeps STAT3 activated; this, in turn, attenuates anti-tumour immune responses [79].

Recently, Hou et al. found that ER- $\alpha$ could suppress STAT3 activity in HCC cell lines and tumour tissues by elevating the expression of protein tyrosine phosphatase receptor type $\mathrm{O}$ (PTPRO) in female mice [80]. In E2treated mice, an increased PTPRO level significantly inhibited HCC. Mechanistically, ER- $\alpha$ binds to EREs on the promoter of PTPRO then increases its expression. Moreover, it was found that the promoter region is methylated, which inactivates the PTPRO gene in HCC in human and rat models $[81,82]$. Methylation-mediated silencing of suppressor genes promotes carcinogenesis $[83,84]$, but the methylation of ptpro that is modulated by ER- $\alpha$ must still be confirmed. In addition, this group found that PTPRO dephosphorylated STAT3 at Y705 and S727 then attenuated STAT3 signalling. Therefore, we could conclude that ER- $\alpha$ regulates STAT3 signalling by inhibiting IL- 6 before STAT3 activation and directly suppressing STAT3 activity through PTPRO activation.

\section{Recruitment of ER-a depends on FOXA1/2}

To exert multiple functions of estrogen, a ligand-bound ER must recognize ERE in target promoters. Previous studies have shown Foxa1/2 are involved in liver development and biological activity [85-88]. Additionally, in breast and prostate, the recruitment of ER- $\alpha$ and androgen receptor (AR) to target genes depends on FOXA1 [89-91]. No protective effect of estrogen could be observed in FOXA-deficient mice, and ER- $\alpha$ and AR exerted protective and oncogenic functions in HCC in a FOXA1/2dependent manner [71]. According to this work, ER- $\alpha$ and AR are recruited to their target genes with assistance from FOXA1/2, and an ERE/ARE is found to be adjacent to FOXA binding sites on promoters. Moreover, an abundance of single nucleotide polymorphisms (SNPs) of the FOXA2 binding site is found on target genes during HCC progression in women due to attenuated affinity of FOXA2 and ER- $\alpha$ for their targets. In their study, estrogen was also found to enhance liver injury in mutant mice. In addition, genotoxic metabolites from estrogen contribute to carcinogenesis [92], hence, raising the notion that estrogen action in the liver is determined by the overall cellular context, rather than the hormone itself.

\section{Some microRNAs promote HCC through inhibiting ER-a}

Previous studies found that miR-22 was downregulated in HCC and considered as a suppressor of cell proliferation [93]. However, Jiang et al. found that miR-22 was highly expressed in male HCC tumour adjacent tissue, and this expression was correlated with decreased ER $\alpha$ expression [66]. Furthermore, they showed that miR-22 inhibited ER- $\alpha$ transcription by directly targeting its 3 ' UTR region, which was consistent with a previous study [94]. The deprivation of the anti-tumour effect of ER- $\alpha$ caused by miR-22 led to the carcinogenic process of adjacent liver tissues. Intriguingly, miR-18a, which has a high expression pattern in HCC tumour tissues, was also found to suppress the transcription of the ER- $\alpha$ gene [95]. However, miR-18a was not an inducer of female benign hepatoma in their research, which supported the notion that HCC and benign hepatoma are caused by distinct mechanisms. Actually, malignant transformation of OCPs-induced hepatic adenoma made estrogen as a HCC-promoting factor in early clinical trials [10].

Another study raised the possibility that miR-26a could prevent hepatoma cell growth through the repression of ER- $\alpha$ [96]. However, the marked decrease of ER$\alpha$ and miR-26a in HCC tumour tissues indicated that downregulation of ER- $\alpha$ in HCC is mediated by a complex cellular network and not only by miR-26a.

\section{Role of ER- $\beta$ in liver disease requires more investigation} ER- $\beta$ shows strong anti-proliferative $[97,98]$ and antiinflammatory properties [99], and it is detected more 
frequently in patients with chronic liver disease than those with HCC [32], which implicates a protective role of ER- $\beta$ in liver disease. Moreover, it has been shown that ER- $\beta$ is overexpressed in HCV-related HCC tissues, but not in HBV-related tissues [100], suggesting that different mechanisms of HCC progression are induced by $\mathrm{HCV}$ and HBV. However, previous work showed the HBsAg could upregulate ER- $\beta$ in $H B s A g$ transgenic male mice, which raises the possibility that HBV infection may contribute to the gender disparity of HCC [101]. Intriguingly, ER- $\beta$ displays anti-tumour effects in intrahepatic cholangiocarcinoma (IHCC) [102]. We believe that a better understanding of the roles of ER- $\beta$ in liver disease will yield opportunities to develop novel therapies.

TAMs define an invasive microenvironment to promote tumour progression through multiple signalling pathways [103,104]. M2-polarised TAMs promote angiogenesis, metastasis and immune suppression by the secretion and modulation of cytokines, chemokines and growth factors [61]. A recent report revealed that the inhibition of the JAK/STAT6 pathway reduced TAMs polarization, thus suppressing HCC growth [105]. Such an effect is specifically caused by ER- $\beta$-induced SOCS1 expression. This finding indicates the protective role of estrogen through ER- $\beta$ binding, but intriguingly, ER- $\beta$ restrains the progression and metastasis of hepatoma [105]. In addition, unliganded ER- $\beta$ regulates three classes of genes, whereas ER- $\alpha$ must be ligand-bound to regulate its target genes [106]. These findings provide novel insights into the role of ER- $\beta$ in liver cancer.
Unfortunately, the function of ER- $\beta$ in HCC is largely unclear and requires further investigation.

\section{The synthesis of estrogen by aromatase in HCC}

Elevated aromatase expression has been detected in hepatitis and HCC [107-109]. Intratumoural aromatase is considered a key inducer of estrogen-dependent neoplasm, such as breast, endometrial, and surface epithelial-stromal ovarian carcinomas [110]. The aromatase inhibitor fadrozole hydrochloride was demonstrated to counter spontaneous HCC in rats [111]. However, the contribution made by aromatase to the tumour microenvironment has not yet clarified. The elevated activity and expression of aromatase was detected in malignant human liver tissues and cells [108], and the influence of polymorphisms of the CYP19 (aromatase) promoter is associated with risk for HCC [112]. However, no conclusive evidence could be found to mechanistically link local estrogen production to $\mathrm{HCC}$ development. Consistent with the notion that estrogen prevents HCC by anti-inflammation effect, aromatase was found to be a risk factor only in non-viral hepatitisrelated $\mathrm{HCC}$.

\section{Conclusion}

The effect of estrogen in HCC has turned from an oncogenic to protective role based on recent discoveries. Androgen promotes the development of liver and prostate cancer [113,114], whereas estrogen plays an oppositing

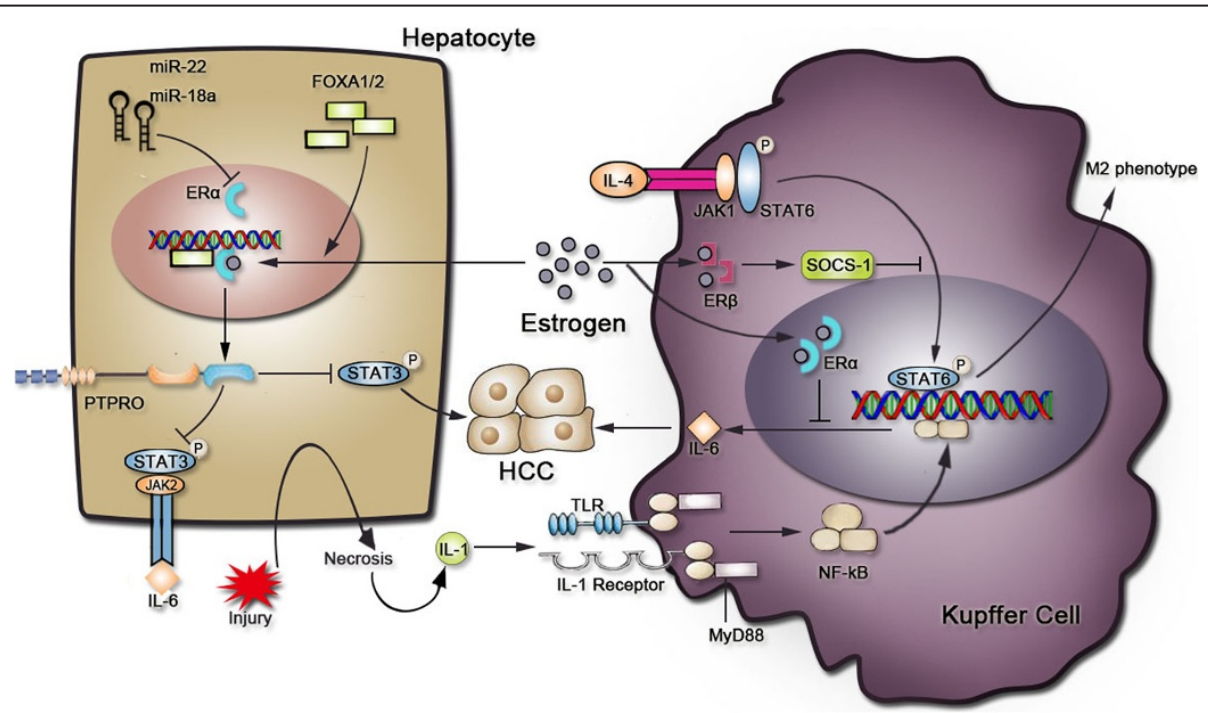

Figure 2 Estrogen inhibits HCC development through its anti-inflammatory effects. Estrogen exerts its protective effects through different pathways in KCs and hepatocytes. Ligand-bound ER- $\beta$ inhibits M2 phenotype polarization in the ANA-1 cell line, and this procedure occurs mainly in TAMs, and not in KCs. Several miRNAs promote HCC by inhibiting ER-a. FOXA1/2 assists a ligand-bound ER-a to locate and bind to the ERE, and STAT3 plays a central role in these axes. Necrosis caused by liver injury defines the inflammatory microenvironment in the liver and eventually leads to HCC. 
Table 3 Inhibition of inflammation factors by estrogen in $\mathrm{HCC}$

\begin{tabular}{lll}
\hline $\begin{array}{l}\text { Inflammation } \\
\text { factors }\end{array}$ & Models & References \\
\hline IL-6 & DEN-treated mice & {$[51]$} \\
STAT3 & DEN-treated mice, Huh-7 cells, SMCC- & {$[51,80]$} \\
& 7721 cells & \\
NF-KB & DEN-treated mice, HepG2 cells, H22 cells & {$[51,118,121]$} \\
TAMs & Orthotopically and ectopically implanted & {$[105]$} \\
& HCC mice, coculture system of & \\
& macrophages and Hepa1-6 cells & \\
\hline
\end{tabular}

role in the development of breast cancer and HCC $[51,115,116]$. How does such an antagonism exist? Pioneer work on this issue revealed that synthetic estrogen might promote liver carcinogenesis after DEN treatment in animal models [15-19]. Indeed, the precedence of estrogen or DEN treatment seems to have opposite effects on HCC development. Administration of estrogen prior to carcinogenic events such as DEN treatment, is believed to protect the liver from HCC [28], and this phenomenon is supported by a human model because estrogen usually functions in females before HCC initiation. Another possible mechanism for the oncogenic effect of estrogen is illustrated in the DEN-treatment model, where the NF- $\mathrm{kB}$ pathway is inhibited in hepatocytes (not in $\mathrm{KCs}$ ). Blockage of NF-kB signalling in DEN-treated hepatocytes promotes carcinogenesis, because hepatocytes suffer severe cell death through necrosis and apoptosis [67]. In contrast, the inhibition of NF- $\mathrm{kB}$ signalling has a suppressive effect in hepatocytes of $\mathrm{Mdr}^{-1-}$ mice, which is an inflammation-associated liver cancer model [68], consistent with the result in Huh7 cells [117]. Moreover, estrogen is found to attenuate $\mathrm{HCC}$ progression by regulating cell proliferation, invasion and apoptosis by inhibiting ER- $\alpha$-induced NF- $\mathrm{KB}$ signalling [118]. NF- $\kappa B$ is highly associated with cancerrelated inflammation, and estrogen inhibits NF- $\mathrm{kB}$ signalling; therefore, a novel model that fully captures the complex behavior of human HCC generation is required to understand the molecular mechanism by which the origin of HCC is modulated [119].

With emerging evidence supporting $\mathrm{HCC}$ as an inflammation-related cancer [59], we speculate that estrogen may, at least partially, play its protective role through its anti-inflammation effects. As described in detail in Figure 2, estrogen is involved in the regulation of the inflammation network in HCC by restraining of proinflammatory cytokines and inhibiting downstream signalling pathways. However, it is also reported that estrogen promotes hepatocytes proliferation [120]. Here, we believe that estrogen exerts promoting and inhibiting effects on HCC development, but, in tumour milieus, it is generally accepted as a mediator of anti-inflammation.
The oncogenic effect of estrogen could also play a part in tumourigenesis, as cancer cells will use all of the help they can get. That is, both faces of estrogen are retained in HCC, but it protects females from HCC because inflammation is the key event for HCC development. The cellular milieus help estrogen protect from liver cancer. However, evidence for the anti-inflammatory effect of estrogen in HCC is limited; and uncovering how estrogen protects from HCC development would provide novel therapeutic approaches in drug design and cancer therapy (Table 3).

It is important to bear in mind; however, that estrogen may cause some adverse effects in patients, especially in males, who form the majority of HCC cases. Therefore, the method for using hormone-related therapy to treat $\mathrm{HCC}$ requires rigorous testing and validation. In the future, finding the exact point at which estrogen switches its role from oncogenic to suppressive in HCC will enable us to establish a model to mimic chronic inflammation during HCC development.

\section{Abbreviations \\ HCC: Hepatocellular carcinoma; ER: Estrogen receptor; OCPs: Oral contraceptives; ERE: Estrogen response element; wtER-a: Wild type ER-a; VER-a: Variant ER-a; E2: Estradiol; HBx: Hepatitis B virus X protein; HBS-Ag: Hepatitis B surface antigen; LINE-1: Long interspersed nuclear element-1; KCs: Kupffer cells; DEN: Diethylnitrosamine; Foxa: Forkhead box A; TAMs: Tumour-associated macrophages; STAT: Signal transducer and activator of transcription; SOCS: Suppressor of cytokine signalling; PTPRO: protein tyrosine phosphatase receptor type $\mathrm{O}$.}

\section{Competing interests}

The authors declare that they have no competing interests.

\section{Authors' contributions}

LS performed article searches, drafted the manuscript and figures and revised the manuscript. YF performed language correction and contributed to refinement of the manuscript. $\mathrm{HL}$ and $\mathrm{RM}$ participated in information updating and viewpoint complementarity. XC provided the original idea, administrative support and financial support. All authors read and approved the final manuscript.

\section{Acknowledgements}

This work was supported by National Natural Science Foundation of China (81201942). We thank Yongjie Yin for his help in figure preparation and Anyong Xie for reading the manuscript and making corrections.

Received: 18 December 2013 Accepted: 28 March 2014 Published: 8 April 2014

\section{References}

1. Jemal A, Bray F, Center MM, Ferlay J, Ward E, Forman D: Global cancer statistics. CA Cancer J Clin 2011, 61:69-90.

2. Gomaa Al, Khan SA, Toledano MB, Waked I, Taylor-Robinson SD: Hepatocellular carcinoma: epidemiology, risk factors and pathogenesis. World J Gastroenterol 2008, 14:4300-4308.

3. Venook AP, Papandreou C, Furuse J, de Guevara LL: The incidence and epidemiology of hepatocellular carcinoma: a global and regional perspective. Oncologist 2010, 15(Suppl 4):5-13.

4. Lin S, Hoffmann K, Schemmer P: Treatment of hepatocellular carcinoma: a systematic review. Liver Cancer 2012, 1:144-158.

5. Bruix J, Sherman M: Management of hepatocellular carcinoma: an update. Hepatology 2011, 53:1020-1022.

6. Abou-Alfa GK: Sorafenib use in hepatocellular carcinoma: more questions than answers. Hepatology 2014. 
7. Bosch FX, Ribes J, Diaz M, Cleries R: Primary liver cancer: worldwide incidence and trends. Gastroenterology 2004, 127:S5-S16.

8. Kalra M, Mayes J, Assefa S, Kaul AK, Kaul R: Role of sex steroid receptors in pathobiology of hepatocellular carcinoma. World J Gastroenterol 2008, 14:5945-5961

9. Ma WL, Hsu CL, Yeh CC, Wu MH, Huang CK, Jeng LB, Hung YC, Lin TY, Yeh S, Chang C: Hepatic androgen receptor suppresses hepatocellular carcinoma metastasis through modulation of cell migration and anoikis. Hepatology 2012, 56:176-185.

10. Giannitrapani L, Soresi M, La Spada E, Cervello M, D'Alessandro N, Montalto G: Sex hormones and risk of liver tumor. Ann N Y Acad Sci 2006, 1089:228-236

11. De Maria N, Manno M, Villa E: Sex hormones and liver cancer. Mol Cell Endocrinol 2002, 193:59-63.

12. Pignata S, Daniele B, Gallo C, De Vivo R, Monfardini S, Perrone F: Endocrine treatment of hepatocellular carcinoma. Any evidence of benefit? Eur J Cancer 1998, 34:25-32.

13. Farinati F, De Maria N, Marafin C, Fagiuoli S, Della LG, Naccarato R: Hepatocellular carcinoma in alcoholic cirrhosis: is sex hormone imbalance a pathogenetic factor? Eur J Gastroenterol Hepatol 1995, 7:145-150.

14. Shimizu I, Yasuda M, Mizobuchi Y, Ma YR, Liu F, Shiba M, Horie T, Ito S: Suppressive effect of oestradiol on chemical hepatocarcinogenesis in rats. Gut 1998, 42:112-119.

15. Campen D, Maronpot R, Lucier G: Dose-response relationships in promotion of rat hepatocarcinogenesis by 17 alpha-ethinylestradiol. J Toxicol Environ Health 1990, 29:257-268.

16. Yager JJ, Yager R: Oral contraceptive steroids as promoters of hepatocarcinogenesis in female Sprague-Dawley rats. Cancer Res 1980, 40:3680-3685.

17. Yager JD, Campbell HA, Longnecker DS, Roebuck BD, Benoit MC: Enhancement of hepatocarcinogenesis in female rats by ethinyl estradiol and mestranol but not estradiol. Cancer Res 1984, 44:3862-3869.

18. Cameron R, Imaida K, Ito N: Promotive effects of ethinyl estradiol in hepatocarcinogenesis initiated by diethylnitrosamine in male rats. Gann 1981, 72:339-340.

19. Wanless IR, Medline A: Role of estrogens as promoters of hepatic neoplasia. Lab Invest 1982, 46:313-320.

20. Fechner RE: Benign hepatic lesions and orally administered contraceptives. A report of seven cases and a critical analysis of the literature. Hum Pathol 1977, 8:255-268.

21. Vana J, Murphy GP, Aronoff BL, Baker HW: Primary liver tumors and oral contraceptives. Results of a survey. JAMA 1977, 238:2154-2158.

22. Di Maio M, De Maio E, Morabito A, D'Aniello R, De Feo G, Gallo C, Perrone F: Hormonal treatment of human hepatocellular carcinoma. Ann N Y Acad Sci 2006, 1089:252-261.

23. Maheshwari S, Sarraj A, Kramer J, El-Serag HB: Oral contraception and the risk of hepatocellular carcinoma. J Hepatol 2007, 47:506-513.

24. Villa E, Dugani A, Moles A, Camellini L, Grottola A, Buttafoco P, Merighi A, Ferretti I, Esposito P, Miglioli L, Bagni A, Troisi R, De Hemptinne B, Praet M Callea F, Manenti F: Variant liver estrogen receptor transcripts already occur at an early stage of chronic liver disease. Hepatology 1998, 27:983-988.

25. Villa E, Dugani A, Fantoni E, Camellini L, Buttafoco P, Grottola A, Pompei G, De Santis M, Ferrari A, Manenti F: Type of estrogen receptor determines response to antiestrogen therapy. Cancer Res 1996, 56:3883-3885.

26. Tan CK, Chow PK, Findlay M, Wong C, Machin D: Use of tamoxifen in hepatocellular carcinoma: a review and paradigm shift. J Gastroenterol Hepatol 2000, 15:725-729.

27. Chow PK, Tai BC, Tan CK, Machin D, Win KM, Johnson PJ, Soo KC: Highdose tamoxifen in the treatment of inoperable hepatocellular carcinoma: a multicenter randomized controlled trial. Hepatology 2002, 36:1221-1226.

28. Villa E: Role of estrogen in liver cancer. Womens Health (Lond Engl) 2008, 4:41-50.

29. Yu MW, Chang HC, Chang SC, Liaw YF, Lin SM, Liu CJ, Lee SD, Lin CL, Chen PJ, Lin SC, Chen CJ: Role of reproductive factors in hepatocellular carcinoma: impact on hepatitis B- and C-related risk. Hepatology 2003, 38:1393-1400.

30. Shimizu l: Impact of oestrogens on the progression of liver disease. Liver Int 2003, 23:63-69.

31. El-Serag HB, Mason AC, Key C: Trends in survival of patients with hepatocellular carcinoma between 1977 and 1996 in the United States. Hepatology 2001, 33:62-65.
32. lavarone $M$, Lampertico $P$, Seletti C, Francesca DM, Ronchi G, Del NE, Colombo M: The clinical and pathogenetic significance of estrogen receptor-beta expression in chronic liver diseases and liver carcinoma. Cancer 2003, 98:529-534.

33. Barone I, Brusco L, Fuqua SA: Estrogen receptor mutations and changes in downstream gene expression and signaling. Clin Cancer Res 2010, 16:2702-2708.

34. Miceli V, Cocciadiferro L, Fregapane M, Zarcone M, Montalto G, Polito LM, Agostara B, Granata OM, Carruba G: Expression of wild-type and variant estrogen receptor alpha in liver carcinogenesis and tumor progression. OMICS 2011, 15:313-317.

35. Villa E, Camellini L, Dugani A, Zucchi F, Grottola A, Merighi A, Buttafoco P, Losi $L$, Manenti F: Variant estrogen receptor messenger RNA species detected in human primary hepatocellular carcinoma. Cancer Res 1995, 55:498-500.

36. Villa E, Moles A, Ferretti I, Buttafoco P, Grottola A, Del BM, De Santis M, Manenti F: Natural history of inoperable hepatocellular carcinoma: estrogen receptors' status in the tumor is the strongest prognostic factor for survival. Hepatology 2000, 32:233-238.

37. Villa E, Colantoni A, Camma C, Grottola A, Buttafoco P, Gelmini R, Ferretti I, Manenti F: Estrogen receptor classification for hepatocellular carcinoma: comparison with clinical staging systems. J Clin Oncol 2003, 21:441-446.

38. Han J, Ding L, Yuan B, Yang X, Wang X, Li J, Lu Q, Huang C, Ye Q: Hepatitis $B$ virus $X$ protein and the estrogen receptor variant lacking exon 5 inhibit estrogen receptor signaling in hepatoma cells. Nucleic Acids Res 2006, 34:3095-3106.

39. Lee LM, Cao J, Deng H, Chen P, Gatalica Z, Wang ZY: ER-alpha36, a novel variant of ER-alpha, is expressed in ER-positive and -negative human breast carcinomas. Anticancer Res 2008, 28:479-483.

40. Villa E, Ferretti I, Grottola A, Buttafoco P, Buono MG, Giannini F, Manno M, Bertani H, Dugani A, Manenti F: Hormonal therapy with megestrol in inoperable hepatocellular carcinoma characterized by variant oestrogen receptors. Br J Cancer 2001, 84:881-885.

41. Barone C, Koeberle D, Metselaar H, Parisi G, Sansonno D, Spinzi G: Multidisciplinary approach for HCC patients: hepatology for the oncologists. Ann Oncol 2013, 24(Suppl 2):i15-i23.

42. Farinati F, Cardin R, Bortolami M, Grottola A, Manno M, Colantoni A, Villa E: Estrogens receptors and oxidative damage in the liver. Mol Cell Endocrinol 2002, 193:85-88.

43. Gao XD, Qu JH, Chang XJ, Lu YY, Bai WL, Wang H, Xu ZX, An LJ, Wang CP, Zeng Z, Yang YP: Hypomethylation of long interspersed nuclear element1 promoter is associated with poor outcomes for curative resected hepatocellular carcinoma. Liver Int 2013, 34:136-146.

44. Kim MJ, White-Cross JA, Shen L, Issa JP, Rashid A: Hypomethylation of long interspersed nuclear element-1 in hepatocellular carcinomas. Mod Pathol 2009, 22:442-449.

45. Hishida M, Nomoto S, Inokawa $Y$, Hayashi M, Kanda M, Okamura Y, Nishikawa Y, Tanaka C, Kobayashi D, Yamada S, Nakayama G, Fujii T, Sugimoto H, Koike M, Fujiwara M, Takeda S, Kodera Y: Estrogen receptor 1 gene as a tumor suppressor gene in hepatocellular carcinoma detected by triple-combination array analysis. Int J Oncol 2013, 43:88-94.

46. Shen L, Ahuja N, Shen Y, Habib NA, Toyota M, Rashid A, Issa JP: DNA methylation and environmental exposures in human hepatocellular carcinoma. J Natl Cancer Inst 2002, 94:755-761.

47. Straub RH: The complex role of estrogens in inflammation. Endocr Rev 2007, 28:521-574.

48. Rogers A, Eastell $R$ : The effect of 17beta-estradiol on production of cytokines in cultures of peripheral blood. Bone 2001, 29:30-34.

49. Polan ML, Loukides J, Nelson P, Carding S, Diamond M, Walsh A, Bottomly $K$ : Progesterone and estradiol modulate interleukin- 1 beta messenger ribonucleic acid levels in cultured human peripheral monocytes. J Clin Endocrinol Metab 1989, 69:1200-1206.

50. Kawasaki T, Ushiyama T, Inoue K, Hukuda S: Effects of estrogen on interleukin-6 production in rheumatoid fibroblast-like synoviocytes. Clin Exp Rheumatol 2000, 18:743-745.

51. Naugler WE, Sakurai T, Kim S, Maeda S, Kim K, Elsharkawy AM, Karin M: Gender disparity in liver cancer due to sex differences in MyD88dependent IL-6 production. Science 2007, 317:121-124.

52. Rodriguez E, Lopez R, Paez A, Masso F, Montano LF: 17Beta-estradiol inhibits the adhesion of leukocytes in TNF-alpha stimulated human endothelial cells by blocking IL-8 and MCP-1 secretion, but not its transcription. Life Sci 2002, 71:2181-2193. 
53. Kanda N, Watanabe S: 17beta-estradiol, progesterone, and dihydrotestosterone suppress the growth of human melanoma by inhibiting interleukin-8 production. J Invest Dermatol 2001, 117:274-283.

54. Gilmore W, Weiner LP, Correale J: Effect of estradiol on cytokine secretion by proteolipid protein-specific T cell clones isolated from multiple sclerosis patients and normal control subjects. J Immunol 1997, 158:446-451.

55. Liu HY, Buenafe AC, Matejuk A, Ito A, Zamora A, Dwyer J, Vandenbark AA, Offner $\mathrm{H}$ : Estrogen inhibition of EAE involves effects on dendritic cell function. J Neurosci Res 2002, 70:238-248.

56. Kanda N, Tamaki K: Estrogen enhances immunoglobulin production by human PBMCs. J Allergy Clin Immunol 1999, 103:282-288.

57. Oursler MJ, Cortese C, Keeting P, Anderson MA, Bonde SK, Riggs BL, Spelsberg TC: Modulation of transforming growth factor-beta production in normal human osteoblast-like cells by 17 beta-estradiol and parathyroid hormone. Endocrinology 1991, 129:3313-3320.

58. Hatthachote P, Gillespie Jl: Complex interactions between sex steroids and cytokines in the human pregnant myometrium: evidence for an autocrine signaling system at term. Endocrinology 1999, 140:2533-2540.

59. Berasain C, Perugorria MJ, Latasa MU, Castillo J, Goni S, Santamaria M, Prieto J, Avila MA: The epidermal growth factor receptor: a link between inflammation and liver cancer. Exp Biol Med (Maywood) 2009, 234:713-725.

60. Mantovani A, Allavena P, Sica A, Balkwill F: Cancer-related inflammation. Nature 2008, 454:436-444.

61. Capece D, Fischietti M, Verzella D, Gaggiano A, Cicciarelli G, Tessitore A, Zazzeroni F, Alesse E: The inflammatory microenvironment in hepatocellular carcinoma: a pivotal role for tumor-associated macrophages. Biomed Res Int 2013, 2013:187204.

62. Prieto J: Inflammation, HCC and sex: IL-6 in the centre of the triangle. J Hepatol 2008, 48:380-381.

63. Nakagawa H, Maeda S, Yoshida H, Tateishi R, Masuzaki R, Ohki T, Hayakawa Y, Kinoshita H, Yamakado M, Kato N, Shiina S, Omata M: Serum IL-6 levels and the risk for hepatocarcinogenesis in chronic hepatitis $\mathrm{C}$ patients: an analysis based on gender differences. Int J Cancer 2009, 125:2264-2269.

64. Wong WW, Yu J, Cheng AS, Wong GL, Chan HY, Chu ES, Ng EK, Chan FK, Sung JJ, Chan HL: High serum interleukin-6 level predicts future hepatocellular carcinoma development in patients with chronic hepatitis B. Int J Cancer 2009, 124:2766-2770.

65. Hsia CY, Huo TI, Chiang SY, Lu MF, Sun CL, Wu JC, Lee PC, Chi CW, Lui WY, Lee SD: Evaluation of interleukin-6, interleukin-10 and human hepatocyte growth factor as tumor markers for hepatocellular carcinoma. Eur J Surg Oncol 2007, 33:208-212.

66. Jiang R, Deng L, Zhao L, Li X, Zhang F, Xia Y, Gao Y, Wang X, Sun B: miR-22 promotes HBV-related hepatocellular carcinoma development in males. Clin Cancer Res 2011, 17:5593-5603.

67. Sun B, Karin M: NF-kappaB signaling, liver disease and hepatoprotective agents. Oncogene 2008, 27:6228-6244.

68. Karin M, Greten FR: NF-kappaB: linking inflammation and immunity to cancer development and progression. Nat Rev Immunol 2005, 5:749-759.

69. Stein $B$, Yang MX: Repression of the interleukin- 6 promoter by estrogen receptor is mediated by NF-kappa B and C/EBP beta. Mol Cell Biol 1995, 15:4971-4979.

70. Lippitz BE: Cytokine patterns in patients with cancer: a systematic review. Lancet Oncol 2013, 14:e218-e228.

71. Li Z, Tuteja G, Schug J, Kaestner KH: Foxa1 and Foxa2 are essential for sexual dimorphism in liver cancer. Cell 2012, 148:72-83.

72. Sica A, Allavena P, Mantovani A: Cancer related inflammation: the macrophage connection. Cancer Lett 2008, 267:204-215.

73. Calvisi DF: Dr. Jekyll and Mr. Hyde: a paradoxical oncogenic and tumor suppressive role of signal transducer and activator of transcription 3 in liver cancer. Hepatology 2011, 54:9-12.

74. He G, Karin M: NF-kappaB and STAT3 - key players in liver inflammation and cancer. Cell Res 2011, 21:159-168.

75. Calvisi DF, Ladu S, Gorden A, Farina M, Conner EA, Lee JS, Factor VM, Thorgeirsson SS: Ubiquitous activation of Ras and Jak/Stat pathways in human HCC. Gastroenterology 2006, 130:1117-1128.

76. Fan Y, Mao R, Yang J: NF-kappaB and STAT3 signaling pathways collaboratively link inflammation to cancer. Protein Cell 2013, 4:176-185.

77. He G, Yu GY, Temkin V, Ogata H, Kuntzen C, Sakurai T, Sieghart W, Peck-Radosavljevic M, Leffert HL, Karin M: Hepatocyte IKKbeta/NF-kappaB inhibits tumor promotion and progression by preventing oxidative stress-driven STAT3 activation. Cancer Cell 2010, 17:286-297.
78. Ogata H, Kobayashi T, Chinen T, Takaki H, Sanada T, Minoda Y, Koga K, Takaesu G, Maehara Y, lida M, Yoshimura A: Deletion of the SOCS3 gene in liver parenchymal cells promotes hepatitis-induced hepatocarcinogenesis. Gastroenterology 2006, 131:179-193.

79. Kortylewski M, Kujawski M, Wang T, Wei S, Zhang S, Pilon-Thomas S, Niu G, Kay H, Mule J, Kerr WG, Jove R, Pardoll D, Yu H: Inhibiting Stat3 signaling in the hematopoietic system elicits multicomponent antitumor immunity. Nat Med 2005, 11:1314-1321.

80. Hou J, Xu J, Jiang R, Wang Y, Chen C, Deng L, Huang X, Wang X, Sun B: Estrogen-sensitive PTPRO expression represses hepatocellular carcinoma progression by control of STAT3. Hepatology 2013, 57:678-688.

81. Motiwala T, Ghoshal K, Das A, Majumder S, Weichenhan D, Wu YZ, Holman K, James SJ, Jacob ST, Plass C: Suppression of the protein tyrosine phosphatase receptor type $\mathrm{O}$ gene (PTPRO) by methylation in hepatocellular carcinomas. Oncogene 2003, 22:6319-6331.

82. Hsu SH, Motiwala T, Roy S, Claus R, Mustafa M, Plass C, Freitas MA, Ghoshal $\mathrm{K}$, Jacob ST: Methylation of the PTPRO gene in human hepatocellular carcinoma and identification of VCP as its substrate. J Cell Biochem 2013, 114:1810-1818.

83. Sceusi EL, Loose DS, Wray CJ: Clinical implications of DNA methylation in hepatocellular carcinoma. HPB (Oxford) 2011, 13:369-376.

84. Calvisi DF, Ladu S, Gorden A, Farina M, Lee JS, Conner EA, Schroeder I, Factor VM, Thorgeirsson SS: Mechanistic and prognostic significance of aberrant methylation in the molecular pathogenesis of human hepatocellular carcinoma. J Clin Invest 2007, 117:2713-2722.

85. Friedman JR, Kaestner KH: The Foxa family of transcription factors in development and metabolism. Cell Mol Life Sci 2006, 63:2317-2328.

86. Sund NJ, Ang SL, Sackett SD, Shen W, Daigle N, Magnuson MA, Kaestner KH: Hepatocyte nuclear factor 3beta (Foxa2) is dispensable for maintaining the differentiated state of the adult hepatocyte. Mol Cell Biol 2000, 20:5175-5183.

87. Bochkis IM, Rubins NE, White P, Furth EE, Friedman JR, Kaestner KH: Hepatocyte-specific ablation of Foxa2 alters bile acid homeostasis and results in endoplasmic reticulum stress. Nat Med 2008, 14:828-836.

88. Kaestner $\mathrm{KH}$ : The FoxA factors in organogenesis and differentiation. Curr Opin Genet Dev 2010, 20:527-532

89. Carroll JS, Liu XS, Brodsky AS, Li W, Meyer CA, Szary AJ, Eeckhoute J, Shao W, Hestermann EV, Geistlinger TR, Fox EA, Silver PA, Brown M: Chromosome-wide mapping of estrogen receptor binding reveals longrange regulation requiring the forkhead protein FoxA1. Cell 2005, 122:33-43.

90. Gao N, Zhang J, Rao MA, Case TC, Mirosevich J, Wang Y, Jin R, Gupta A, Rennie PS, Matusik RJ: The role of hepatocyte nuclear factor-3 alpha (forkhead box $\mathrm{A} 1$ ) and androgen receptor in transcriptional regulation of prostatic genes. Mol Endocrinol 2003, 17:1484-1507.

91. Yu X, Gupta A, Wang Y, Suzuki K, Mirosevich J, Orgebin-Crist MC, Matusik RJ: Foxa1 and Foxa2 interact with the androgen receptor to regulate prostate and epididymal genes differentially. Ann N Y Acad Sci 2005, 1061:77-93.

92. Yager JD, Liehr JG: Molecular mechanisms of estrogen carcinogenesis. Annu Rev Pharmacol Toxicol 1996, 36:203-232.

93. Zhang J, Yang Y, Yang T, Liu Y, Li A, Fu S, Wu M, Pan Z, Zhou W: microRNA22 , downregulated in hepatocellular carcinoma and correlated with prognosis, suppresses cell proliferation and tumourigenicity. $\mathrm{Br} J$ Cancer 2010, 103:1215-1220.

94. Pandey DP, Picard D: miR-22 inhibits estrogen signaling by directly targeting the estrogen receptor alpha mRNA. Mol Cell Biol 2009, 29:3783-3790

95. Liu WH, Yeh SH, Lu CC, Yu SL, Chen HY, Lin CY, Chen DS, Chen PJ: MicroRNA-18a prevents estrogen receptor-alpha expression, promoting proliferation of hepatocellular carcinoma cells. Gastroenterology 2009, 136:683-693.

96. Chen L, Zheng J, Zhang Y, Yang L, Wang J, Ni J, Cui D, Yu C, Cai Z: Tumorspecific expression of microRNA-26a suppresses human hepatocellular carcinoma growth via cyclin-dependent and -independent pathways. Mol Ther 2011, 19:1521-1528.

97. Paruthiyil S, Parmar H, Kerekatte V, Cunha GR, Firestone GL, Leitman DC: Estrogen receptor beta inhibits human breast cancer cell proliferation and tumor formation by causing a G2 cell cycle arrest. Cancer Res 2004, 64:423-428.

98. Strom A, Hartman J, Foster JS, Kietz S, Wimalasena J, Gustafsson JA: Estrogen receptor beta inhibits 17 beta-estradiol-stimulated proliferation of the breast cancer cell line T47D. Proc Natl Acad Sci U S A 2004, 101:1566-1571. 
99. Cvoro A, Tatomer D, Tee MK, Zogovic T, Harris HA, Leitman DC: Selective estrogen receptor-beta agonists repress transcription of proinflammatory genes. J Immunol 2008, 180:630-636.

100. Wang AG, Lee KY, Kim SY, Choi JY, Lee KH, Kim WH, Wang HJ, Kim JM, Park $M G$, Yeom YI, Kim NS, Yu DY, Lee DS: The expression of estrogen receptors in hepatocellular carcinoma in Korean patients. Yonsei Med J 2006, 47:811-816.

101. Wang Y, Cui F, Lv Y, Li C, Xu X, Deng C, Wang D, Sun Y, Hu G, Lang Z, Huang C, Yang X: HBsAg and HBx knocked into the p21 locus causes hepatocellular carcinoma in mice. Hepatology 2004, 39:318-324.

102. Marzioni M, Torrice A, Saccomanno S, Rychlicki C, Agostinelli L, Pierantonelli I, Rhonnstad P, Trozzi L, Apelqvist T, Gentile R, Candelaresi C, Fava G, Semeraro R, Benedetti A, Gaudio E, Franchitto A, Onori P, De Minicis S, Carpino G, Kallin E, Alvaro D, Nilsson S: An oestrogen receptor beta-selective agonist exerts anti-neoplastic effects in experimental intrahepatic cholangiocarcinoma. Dig Liver Dis 2012, 44:134-142.

103. Condeelis J, Pollard JW: Macrophages: obligate partners for tumor cell migration, invasion, and metastasis. Cell 2006, 124:263-266.

104. Bingle $L$, Brown NJ, Lewis CE: The role of tumour-associated macrophages in tumour progression: implications for new anticancer therapies. J Pathol 2002, 196:254-265.

105. Yang W, Lu Y, Xu Y, Xu L, Zheng W, Wu Y, Li L, Shen P: Estrogen represses hepatocellular carcinoma (HCC) growth via inhibiting alternative activation of tumor-associated macrophages (TAMs). J Biol Chem 2012, 287:40140-40149.

106. Vivar OI, Zhao X, Saunier EF, Griffin C, Mayba OS, Tagliaferri M, Cohen I, Speed TP, Leitman DC: Estrogen receptor beta binds to and regulates three distinct classes of target genes. J Biol Chem 2010, 285:22059-22066.

107. Harada N, Ota H, Yoshimura N, Katsuyama T, Takagi Y: Localized aberrant expression of cytochrome P450 aromatase in primary and metastatic malignant tumors of human liver. J Clin Endocrinol Metab 1998, 83:697-702.

108. Castagnetta LA, Agostara B, Montalto G, Polito L, Campisi I, Saetta A, Itoh T, Yu B, Chen S, Carruba G: Local estrogen formation by nontumoral, cirrhotic, and malignant human liver tissues and cells. Cancer Res 2003, 63:5041-5045

109. Granata OM, Cocciadifero L, Campisi I, Miceli V, Montalto G, Polito LM, Agostara B, Carruba G: Androgen metabolism and biotransformation in nontumoral and malignant human liver tissues and cells. J Steroid Biochem Mol Biol 2009, 113:290-295.

110. Sasano $H$, Harada N: Intratumoral aromatase in human breast, endometrial, and ovarian malignancies. Endocr Rev 1998, 19:593-607.

111. Gunson DE, Steele RE, Chau RY: Prevention of spontaneous tumours in female rats by fadrozole hydrochloride, an aromatase inhibitor. Br J Cancer 1995, 72:72-75.

112. Koh WP, Yuan JM, Wang R, Govindarajan S, Oppenheimer R, Zhang ZQ, Yu $M C$, Ingles SA: Aromatase (CYP19) promoter gene polymorphism and risk of nonviral hepatitis-related hepatocellular carcinoma. Cancer 2011, 117:3383-3392.

113. Paulson DF: Carcinoma of the prostate: the therapeutic dilemma. Annu Rev Med 1984, 35:341-372.

114. Smolev JK, Coffey DS, Scott WW: Experimental models for the study of prostatic adenocarcinoma. J Urol 1977, 118:216-220.

115. Hollingsworth AB, Lerner MR, Lightfoot SA, Wilkerson KB, Hanas JS, McCay $\mathrm{PB}$, Brackett DJ: Prevention of DMBA-induced rat mammary carcinomas comparing leuprolide, oophorectomy, and tamoxifen. Breast Cancer Res Treat 1998, 47:63-70

116. Zumoff B: Does postmenopausal estrogen administration increase the risk of breast cancer? Contributions of animal, biochemical, and clinical investigative studies to a resolution of the controversy. Proc Soc Exp Biol Med 1998, 217:30-37.

117. Qiao L, Zhang H, Yu J, Francisco R, Dent P, Ebert MP, Rocken C, Farrell G: Constitutive activation of NF-kappaB in human hepatocellular carcinoma: evidence of a cytoprotective role. Hum Gene Ther 2006, 17:280-290.

118. Xu H, Wei Y, Zhang Y, Xu Y, Li F, Liu J, Zhang W, Han X, Tan R, Shen P: Oestrogen attenuates tumour progression in hepatocellular carcinoma. J Pathol 2012, 228:216-229.
119. Francavilla A, Polimeno L, Barone M, Azzarone A, Starzl TE: Hepatic regeneration and growth factors. J Surg Oncol Supp/ 1993, 3:1-7.

120. Kalaitzidis D, Gilmore TD: Transcription factor cross-talk: the estrogen receptor and NF-kappaB. Trends Endocrinol Metab 2005, 16:46-52.

121. Harnish DC, Scicchitano MS, Adelman SJ, Lyttle CR, Karathanasis SK: The role of $\mathrm{CBP}$ in estrogen receptor cross-talk with nuclear factor-kappaB in HepG2 cells. Endocrinology 2000, 141:3403-3411.

doi:10.1186/1479-5876-12-93

Cite this article as: Shi et al:: Role of estrogen in hepatocellular carcinoma: is inflammation the key? Journal of Translational Medicine 2014 12:93

\section{Submit your next manuscript to BioMed Central and take full advantage of:}

- Convenient online submission

- Thorough peer review

- No space constraints or color figure charges

- Immediate publication on acceptance

- Inclusion in PubMed, CAS, Scopus and Google Scholar

- Research which is freely available for redistribution 